Okajimas Fol. anat. jap., 40 : 481-495, 1965

\title{
Histochemical Investigations on the Fundic Glands in the Japanese Monkeys (Macaca fuscata Yakui)
}

\author{
by \\ Masatake Imai, Taizo Shibata and Takao Mineda \\ Department of Anatomy, School of Dentistry, Aichi-Gakuin University \\ Chikusaku, Nagoya, Japan
}

\section{Introduction}

There are numerous reports on the histological and histochemical studies or electron microscopy in the human and animal gastric glands, while such studies are few in the monkey. Mi y g a w a and $\mathrm{N}$ is hi (1922) investigated on the distribution in the cardiac, fundus and pyloric glands of the Japanese monkeys. Toki and $\mathrm{Ts} \mathrm{ukamoto}$ (1953) reported on the distribution in the parietal cells in four Formosan monkeys and one Japanese monkey, but the above mentioned two observations were not made for investigations on the gland cells themselves. Moreover, we do not know the histochemical investigations on the gastric glands in the monkey, and such accurate observations are not reported on the same glands in man and other animals for which various kinds of staining method are used. The present authors therefore have made this. study on the monkey.

\section{Materials and Methods}

Each two adult male and female Japanese monkeys (Macaca fuscata Yakui) were used in the present study. The animals were all killed by a rapid intravenous injection of $1.5 \mathrm{cc}$ of Nembutal. No. $1(\delta)$ and No. 2 (ㅇ) had scarce feed in their stomachs, which No. $3(\hat{)})$ had plenty and No. $4(q)$ full of feed. The materials. used in the present study were taken in as fresh a state as possible from the fundus, lesser and greater curvature regions. The tissues were fixed in Altmann's fluid (for the investigations of the mitochondria and the secretory granules), Carnoy's fluid (for pyronin-methylgreen stain and polysaccharide) and buffered formalin (for fatty substances, polysaccharide, mucin and so forth), embedded in paraffin and cut in 4-6 $\mu$ thick sections. For studies of fatty substances, the fixed pieces embedded in phenolgelatin and frozen 
sections of about $10 \mu$ thickness were made. The sections wer stained with hematoxylin (Harris)-eosin, mucicarmine (M e y e r' method), W e ig e r t's iron hematoxylin, $\mathrm{H}$ e ide $\mathrm{n}$ ha in's iron hematoxylin (for the secretory granules), pyronin-methylgreen, 1.0\% cresyl violet and $0.1 \%$ thionin (for the metachromasia). Besides Lillie's PAS method, Feulgen reaction, argentaffine reaction (M a s o n's method) and pseudoplasmal reaction were tried. Altman $\mathrm{n}-\mathrm{Kull}$ 's method was used for staining the mitochondria, and Selig ma n's method for investigations on the succinic dehydrogenase. Fatty substances were stained with Sudan III, Sudan black B (after Lison), scarlet red, Nile blue sulfate and Victoria blue (after Nakanishi).

\section{Observations}

There are five types of cells in the fundic glands.

1. Parietal cells (Figs. 1, 2, 3, 4, 5, 6, 7, 8, 9 and 10): They are generally numerous in the upper one half to two-third of the glands and they are few in the bottom but in the neighboring area of the pylorus, they are distributed in great number even in the bottom of the glands (Fig. 1), while they are very few in the fundus and greater curvature regions (Fig. 3). Thereby it is possible that no parietal cell is found in the sections of these regions. The nucleus with clear nucleolus is larger but has less DNA than that of the chief cell. The cytoplasm contains numerous coarse granules which are clearly stainable with $\mathrm{Heide} \mathrm{nhain}$ 's iron hematoxylin and Sudan black B (Fig. 4) and these granules are also stainable with eosin and Victoria blue, but are unstainable with Masson's method (for argentaffine reaction). We can find many coarse, dark lilac granules in the cytoplasm of the parietal cells which are stained with Nile blue sulfate, and in this case, many small and big red drops are found in the gastric pits. The cytoplasm is, with Sudan III and scarlet red, stained light orange but darker than that of the chief cell, and we can find numerous dark orange coarse granules (Fig. 5) and many red droplets in the cytoplasm. When we use Victoria blue, many dark blue droplets are found in the parietal cells. The pseudoplasmal reaction in the cytoplasm is negative. The parietal cell contains numerous ellipsoidal and short rod-shaped mitochondria and these resemble the above mentioned granules in shape and size (Fig. 9). The cytoplasm does not show such alveolar structure as that of the chief 
or mucous cell, and is slightly reactive to the PAS reaction but is not stained with the mucin staining technique, and PAS positive granules generally do not appear (Fig. 6). However, we can find many large vacuoles and PAS positive coarse granules in the parietal cells in the stomach which was filled with feed (No. 4, Figs. 5 and 7). When the gastric mucosa are treated with Seligman's method for succinic dehydrogenase, the parietal cells react intensively (Fig. 10). The parietal cell contains RNA in very small quantity (after pyronin-methylgreen stain and metachromasia with cresyl violet and thionin, Fig. 8).

2. Chief cells (Figs. 1, 2, 3, 9, 10, 11, 12, 14, 15 and 16): These distribute in the bottom of the fundic glands (Figs. 1 and 2) and sometimes they are also found in the middle part. However, only a few chief cells are found in the bottom of the glands in the neighboring area of the pylorus, because there are numerous parietal cells in this region (Fig. 1). The nuclei of the chief cells are smaller than those of the parietal cells and the mucous cells (Figs. 12 and 13), but their DNA is found in the greatest quantity of all (after Feulgen reaction). The cytoplasm in the bottom of the cell (around the nucleus) is strongly basophile (Figs. 1, 2 and 3), the PAS reaction appears very slightly (Fig. 12) but dark color of this reaction is seen in the free surface of the cell and mucin is provable in this place. The cytoplasm of the chief cell especially the one in the surrounding region of the nucleus shows vivid color of RNA with pyronin-methylgreen stain and strong metachromasia is caused with cresyl violet and thionin (Fig. 14). The reticular framework in the cytoplasm is made clearly except in the surrounding region of the nucleus in the paraffin and frozen sections which are stained with various kinds of staining method (Fig. 12). While the cytoplasm is slightly stained light orange with Sudan III and scarlet red. Moreover, we can observe numerous red droplets in it. The alveoli in the cytoplasm are filled with large round drops which are stained dark brown with Sudan black B (after Lis o n), dark blue with Victoria blue (Fig. 16) and light violet with Nile blue sulfate. These round drops are also reactive to the argentaffine reaction (after Masson) and the secretory granules which are stained with $\mathrm{H}$ e id e $\mathrm{nh}$ a i n's iron hematoxylin are much smaller (Fig. 15) than the above mentioned fatty drops. The chief cell contains many round and short rod-shaped mitochondria but these are less and much smaller than those in the parietal cell (Fig. 9). We can find the activity of the succinic dehydrogenase in the chief cell but it 
is less strongly stained than the parietal cell (after Selig ma n'method, Fig. 10).

3. Mucous cells (Figs. 11, 13, 14, 17 and 18): These can be divided into three types. The I type cells are scattered between the chief cells in the bottom of the glands. The II type cells occupy the middle part and sometimes the bottom of the gland is composed even only of these cells. On the other hand, a few of these cells are found in the upper part of the gland and the greater part of the gland is composed of the chief cells (No. 4). The III type cells (the mucous neck cells) are found in the neck and the upper part of the glands. The I type cells are much alike in the structure of cytoplasm and nuclei of the chief cells except the fact that they contain a little mucin (Fig. 11). The II type cells contain larger and brighter nuclei than those of the chief cells (Fig. 13). The nuclei are usually round or oval but if the parietal cells are numerous and the II type cells lie between them, they are pressed by the parietal cells and not only the cells but also the nuclei are deformed. The deformity in the nucleus is also caused by filling of mucin in the cell. Marked reticular frame-work is made in the cytoplasm of the II type cell, and the above mentioned area is strongly reactive to the PAS reaction (Fig. 13) and is also stained with the mucin staining technique, while, it is slightly stained with pyronin-methylgreen and weak metachromasia with cresyl violet and thionin is found (Fig. 14). Moreover, this cell does not contain such the fatty droplets as those of the chief cell which are stained with Victoria blue and Sudan black B, however, a few little round mitochondria are contained. The III type cell contains a large and bright nucleus and the cytoplasm does not make such reticular framework as that of the II type cell (Fig. 18), and when the cell is filled with mucin, the cytoplasm is brightly seen as a whole. If the III type cells lie between the parietal cells, they are pressed by the latters and the cells and nuclei are deformed. The cytoplasm in the III type cell is weakly reactive to the PAS reaction and contains a little or no mucin (Fig. 18), and is weakly stained with pyronin-methylgreen and cresyl violet (Fig. 17), but contains numerous small granules which are stained dark blue black with Sudan black $B$ and dark blue with Victoria blue. These granules can not be observed in the II type cells. Many little ellipsoidal and short rod-shaped mitochondria and numerous coarse secretory granules are also found in the III type cells.

4. Basal clear cells (Fig. 19): These are scattered singly 
between the basement membrane and the chief calis in the fundic glands but are few in number and are, for the most part of them, found in the bottom of the glands. They have round or somewhat flattened forms and contain large round nuclei with clear nucleoli. The nuclei are slightly larger or as large as those of the chief cells and the chromatin is plenty. The narrow cytoplasmic area that is slightly stained with pyronin-methylgreen is found around the nucleus. Sometimes the cytoplasm shows a network but is eosinophile and contains scarcely any granules, namely the argentaffine reaction is negative, so the area is bright. The cytoplasm is PAS negative, and the metachromasia appears slightly or not with cresyl violet. The granules which are stainable with Sudan black B, Sudan III and Victoria blue are very few.

5. Argentaffine cells (Fig. 20): They are rarely found in the area where the basal clear cells appear, and have round or somewhat flattened forms and there are more cytoplasm in the argentaffine cells than in the basal clear cells and their nuclei have great resemblance to those of the chief cells in the size and the quantity of the chromatin. The cytoplasm contains numerous coarse argentaffine granules, and these granules are also eosinophile and are stainable in yellow green with Victoria blue, blue black with Sudan black $B$, yellow red with pyronin-methylgreen, and are weakly stainable with W e i ge r t's iron hematoxylin, slightly PAS positive and faint metachromasia appears with cresyl violet.

\section{Discussion \\ Parietal cells}

Yany investigators have reportad on the distribution of the parietal cells in a man and many kinds of animal, yet the histochemical studies on this cell are few. Nagayo and $\mathrm{Sawada}$ $(1958,1959)$ studied on the succinic dehydrogenase and the cytochrome oxidase in these cells in the rat and the mouse, and observed numerous granules in those which were strongly reactive for these enzyme. They concluded that these granules were closely connected with the mitochondria. Some observations with the electron microscope on these cells were made by $Y$ a mad a (1964) in the mouse and $B l o 0 m-F a w c e t t(1962)$ in the bat, and they proved many large round mitochondria. The present authors have tried various kinds of staining technique on these cells in four Japanese monkeys 
and attained the following results.

The coarse granules which are contained in the parietal cells are eosinophile, stained slightly with W e ig e r t's iron hematoxylin, weakly reactive to the PAS reaction but are not stained by the mucin staining technique. The granules are stainable in dark orange with Sudan III and scarlet red. Sudan black B, Victoria blue and $\mathrm{Heidenhain's} \mathrm{iron} \mathrm{hematoxylin} \mathrm{stain} \mathrm{the} \mathrm{granules}$ remarkably. There also appear many large granules of dark lilac in the sections for which Victoria blue were used. On the other hand, the parietal cells contain numerous large ellipsoidal and short rod-shaped mitochondria in the cytoplasm and when the gastric mucosa are stained by Seligman's method for the succinic dehydrogenase, the parietal cells react intensively and numerous coarse granules are found in the cytoplasm. Depending on their above mentioned investigations, the present authors consider that some of the same coarse granules which are stainable with various kinds of stain technique are probably the mitochndria, and these granules contain at least two kinds of fatty substance. Besides these coarse granules, it is possible that there mixed some many secretory granules in them, but it was indestinguishable morphologically by the staining techniques which were used by the present authors. It is necessary, for the solution of this problem, to observe minutely the increase and decrease of these granules resulted from the function of these cells. The present authors note in parentheses that they investigated many large vacuoles and PAS positive granules in the parietal cells in the stomach which was filled with feed. There are many red droplets in the cytoplasm of these cells which were treated with Sudan III and scarlet red and dark blue droplets which were stained with Victoria blue. The parietal cells have less RNA than the chief cells.

\section{Chief cells}

They contain basophile cytoplasm in the surrounding regions of the nuclei and these regions are strongly stained with pyroninmethylgreen. Marked reticular-framework comes into sight by various kinds of stain technique in the cytoplasm except in the above mentioned area. But these alveoli are filled with large round drops which are clearly stainable with Sudan black B (after L is o n) and Victoria blue, and are much larger than the secretory granules which are stained with $\mathrm{Heidenhain's} \mathrm{iron} \mathrm{hematoxylin.} \mathrm{The}$ 
drops are found not only in the alveoli but also in the surrounding regions of the nuclei and the glandular ducts. $\mathrm{Nak}$ a is hi (1952) observed the same ones in the chief cells in the rabbit and said that these were free lipoid. Moreover, we can find that many other fatty droplets in these cells are stained in red with Sudan III and scarlet red, and the above mentioned drops are also stainable in light violet with Nile blue sulfate, so it seems that neutral fat is also contained in these cells. The chief cells are almost PAS negative and yet, though in small quantity, PAS positive substances is frequently found in the free surfaces of the cells and mucin is also provable in the areas. Besides, we can observe the appearance of this substance in various quantities in the individual cells. The nucleus of the chief cell is comparatively small and dark due to rich chromatin but it becomes larger and brighter with increase of mucin. In this way, the chief cells change into the mucous cells of type I and II. Therefore, the bottom of the fundic gland is frequently made up of these cells only, and changing into the mucous cells, RNA in the cytoplasm decreases in quantity. The parietal cells are very few in the fundus and the greater curvature regions in the Japanese monkey and this fact is suitable for the investigation in the relation between the chief cells and the mucous cells. If the parietal cells are numerous, the mucous cells are pressed by the former and their form, together with their nuclei, are deformed, and transition from the chief cells to the mucous cells can not be observed. Namely, the Japanese monkey is fitted for these observations. The mitochondria in the chief cells are less and far smaller than those of the parietal cells and the reaction in the chief cells for the succinic dehydrogenase is more weakly. reactive than the parietal cells.

\section{Mucous cells}

The present authors consider that the mucous cells are divided into three types and I and II type cells are derived from the chief cells and they have descrived about this in the part of the chief cells. These completed cells filled with mucin have light and large nuclei and show marked reticular framework, fatty droplets and secretory granules are almost unstainable with various kinds of staining method in the alveolar regions. Few mitochondria are found and RNA is scanty in these cells. While, the cytoplasm of the III type cells which are distributed in the neck and the upper 
part of the fundic glands do not compose the reticular framework, and have smaller quantity of mucin and PAS positive substance than those of the type II. Sometimes, these cells do not contain the above mentioned substances, but have numerous small granules which are clearly stainable with Sudan black B and Victoria blue, and these granules are much smaller than those of the chief cells. $\mathrm{Nak}$ a n is hi (1952) who described on these granules in the chief cells in the rabbit was silent on those in the type III. The III type cells also contain many such small mitochondria as those of the chief cells, so the present authors distinguished the type III from the type II according to the above mentioned different points between the two, and consider that the III type cells are not originated in the chief cells.

\section{Basal clear cells}

Sometimes they are found chiefly in the bottom of the fundic glands and have round or somewhat flattened forms. Narrow and homogeneous cytoplasmic area is found around the nucleus and no argentaffine granules are contained, and the area is light, eosinophile, PAS negative and is with scanty RNA.

\section{Argentaffine cells}

We can find a few these cells which are singly scattered between the basement membrane and the chief cells in the area where the basal clear cells are found. The form is somewhat flattened and the cytoplasm is plentier than that of the basal clear cell and contains numerous coarse argentaffine granules. These granules are eosinophile, and are stained in yellow green with Victoria blue, yellow red with pyronin-methylgreen and are slightly PAS positive. U c h id a (1958) observed on the basal clear cells and the argentaffine cells in a man, rabbit, rat, dog, pig and horse very minutely and concluded that the basal clear cells were immature types of the argentaffine cells. The present authors have no opinion to add to his.

\section{Conclusion}

The present authors have made a histochemical observations on the cells in the fundic glands in four Japanese monkeys (Macaca fuscata Yakui) and conclude as follows. 
1) The parietal cells are numerous in the neighboring region of the pylorus and very few in the fundus and the greater curvature region. These cells contain numerous coarse granules which are stainable with many kinds of staining technique and some of these granules are mitochondria which show intensive reactivity for the succinic dehydrogenase and the reactivity is stronger than that in the chief cells. Free fatty substances which are stainable with Sudan III and Nile blue sulfate are contained in their cytoplasm.

2) The chief cells are almost PAS negative, but its positive color is frequently seen in the free margin of these cells and mucin is also provable in the same portion, and we can observe many kinds of mucous cell containing mucin in different degree. The present authors consider that the mucous cells which are distributed in the middle and lower part of the glands (type I and II) originate in the chief cells.

3) The cytoplasm in the chief cells contain numerous large round drops which are stainable with Sudan black B and Victoria blue and these granules are much larger than the secretory granules and are considered lipoidal substance. Moreover, we can find many fatty droplets which are stainable with Sudan III and scarlet red in these cells.

4) The mucous cells which are found in the neck and the upper part of the glands (the mucous neck cells) are different from the same named cells which are distributed in the middle and lower part of the glands (type I and II). According to the many different points between the mucous neck cells and the mucous cells of type I and II, the present authors consider that the former mucous cells do not originate in the chief cells.

5) B loom-Faw cett (1962) described, "It is possible that the zymogenic cells may arise from the mucous neck cells", but depending on the origin of the mucous cells of type I and II and the structures in the cytoplasm of the so-called mucous neck cells, the present authors can not agree to $\mathrm{Bl}$ oo m-F a w cet t's opinion.

6) On the basal clear cells and the argentaffine cells, the present authors have nothing to add to the observations of the other investigators.

\section{References}

1) Bloom, W. and Fawcett, D.W. 1962: A Textbook of Histology, 8th Edit., pp. 431-442. 
2) Hi1l, W.C.O. 1957: Comparative Anatomy and Taxonomy, III Pithecoidea, p. 43.

3) Hos ok aw a, H. and Ka mi y a, T. 1961-2: Anatomical Sketches of Viscerai Organs of the Mountain Gorilla (Gorilla gorilla beringei). Primates, Journal of Primatology, Vol. 3, No. 1, pp. 13, 26.

4) In o u e, M. and $\mathrm{H}$ a y a m a, S. 1961-2: Histopathological Studies on Two Mountain Gorilla Specimens (Gorilla gorilla beringei) “Munidi \& Emmy". Primates, Journal of Primatology, Vol. 3, pp. 32, 38.

5) Is him a ru, S. and Kad a, K. 1956: An Electron-microscopic research for the chief and parietal-cell of the stomach. Kaibogaku Zassi, Vol. 31, p. 86.

6) $\mathrm{K}$ i d a, Y. 1938: Zytologische Untersuchungen über die Magenschleimhaut des Menschen. 1. Zur Kenntnis der Belegzellen der Fundusdrüsen. Kaibogaku Zassi, Bd. 11, H. 5, pp. 409-420.

7) Kurosum i, K., Shibas a ki, S. and U chid a, G. 1958: An electron microscopy of the rat gastric mucosa. Kaibogaku Zassi, Vol. 33, p. 7.

8) $\mathrm{M}$ i y a g a w a, Y. and $\mathrm{N}$ is h i, G. 1922: Beiträge zur Kenntnis über die Verbreitung der Magendrüsen. Tokyo Iji Shinshi, pp. 19-26.

9) Mor i, I. 1938: Über die Entwicklung der Magenschleimhaut des Menschen und des Kaninchens. Kaibogaku Zassi, Bd. 11, pp. 174-269.

10) N a k a n is h i, T. 1952: Färbung der Fundokorpusdrüsen des Kaninchenmagens mit Viktoria blau. Arch. hist. jap., Vol. 4, pp. 91-95.

11) Nag a y o, T. and $\mathrm{Sa}$ w a d , Y. 1958: Histochemical Studies of the Gastric Parietal Cells, especially on the Succinic Dehydrogenase. The Journal of the Nagoya City University Medical Association. Vol. 8, p. 254.

12) $\mathrm{Nag}$ a y o, T. and $\mathrm{S}$ a w a d a, Y. 1959: Histochemical Studies of the Gastric Parietal Cells. Especially the Fate of Succinic Dehydrogenase During Regeneration and Differentiation of these Cells. Nagoya Medical Journal, Vol. 5, p. 69.

13) Toki , S. and Tsuka moto, A. 1953: The distribution of parietal cells in the stomach in monkeys. Okajimas Fol. anat. jap., Bd. 25, ss. 27-36.

14) Uchida, G. 1958: Cytologische und histologische Untersuchungen über die , basalen hellen Zellen' in den Magen drüsen mit besonderer Berücksichtigung ihrer Beziehung $z u$ den gelben Zellen (chromaffinen Zellen). Arch. hist. jap., Vol. 15, pp. 435-474.

15) U ch id a, G. 1958: Studies on the basal clear cells (basale helle Zelle) in the human gastric gland. Kaibogaku Zassi, Vol. 33, p. 8.

16) Y a m a d a, E. 1964: Histological atlas with the elctron microscope, pp. 153-158. 


\section{Plates}




\section{Explanation of Figures}

Fig. 1. Fundic glands in the neighboring region of the pylorus. The chief cells (1) are strongly stained with hematoxylin and the parietal cells (2) are numerous. Hematoxylin-eosin stain. 130X.

Fig. 2. Fundic glands in the lesser curvature region. The glands are shorter than those in the neighboring region of the pylorus and yet the parietal cells (2) are numerous. 1: Chief cells. Hematoxylin-eosin stain. 130X.

Fig. 3. Fundic glands in the fundus region. The glands are very short and the parietal cells are scarcely found. $\nearrow$ : Chief cells. Hematoxylin-eosin stain. $130 \times$.

Fig. 4. Coarse granules in the parietal cells $(\nearrow$ ) stained with Sudan black B (after Lison). $1000 x$.

Fig. 5. Coarse granules in the parietal cells $(\nearrow)$ stained with Sudan III, containing large vacuoles (1). The stomach was filled with feed. $600 \times$.

Fig. 6. Parietall cells $(\nearrow)$ are weakly reactive to the PAS reaction and PAS positive granules are not found in the cytoplasm. 1000x.

Fig. 7. PAS positive coarse granules in the parietal cell $(\nearrow)$. The stomach was filled with feed. $1000 \times$.

Fig. 8. Metachromasia with cresyl violet is not seen in the parietal cells $(\nearrow)$. $1000 \times$.

Fig. 9. Mitochondria in the chief cell (1) and the parietal cells (2). Mitochondria in the latter are large and numerous. A $1 \mathrm{tm}$ a $\mathrm{n} \mathrm{n}-\mathrm{Ku} \mathrm{ll}$ 's method. $1000 \mathrm{x}$.

Fig. 10. Chief cell (1) is weakly reactive to succinic dehydrogenase, while, the parietal cells (2) are intensively reactive to the same named enzym. Seli $g$ $m$ a n's method. $1000 x$. 
Plate I
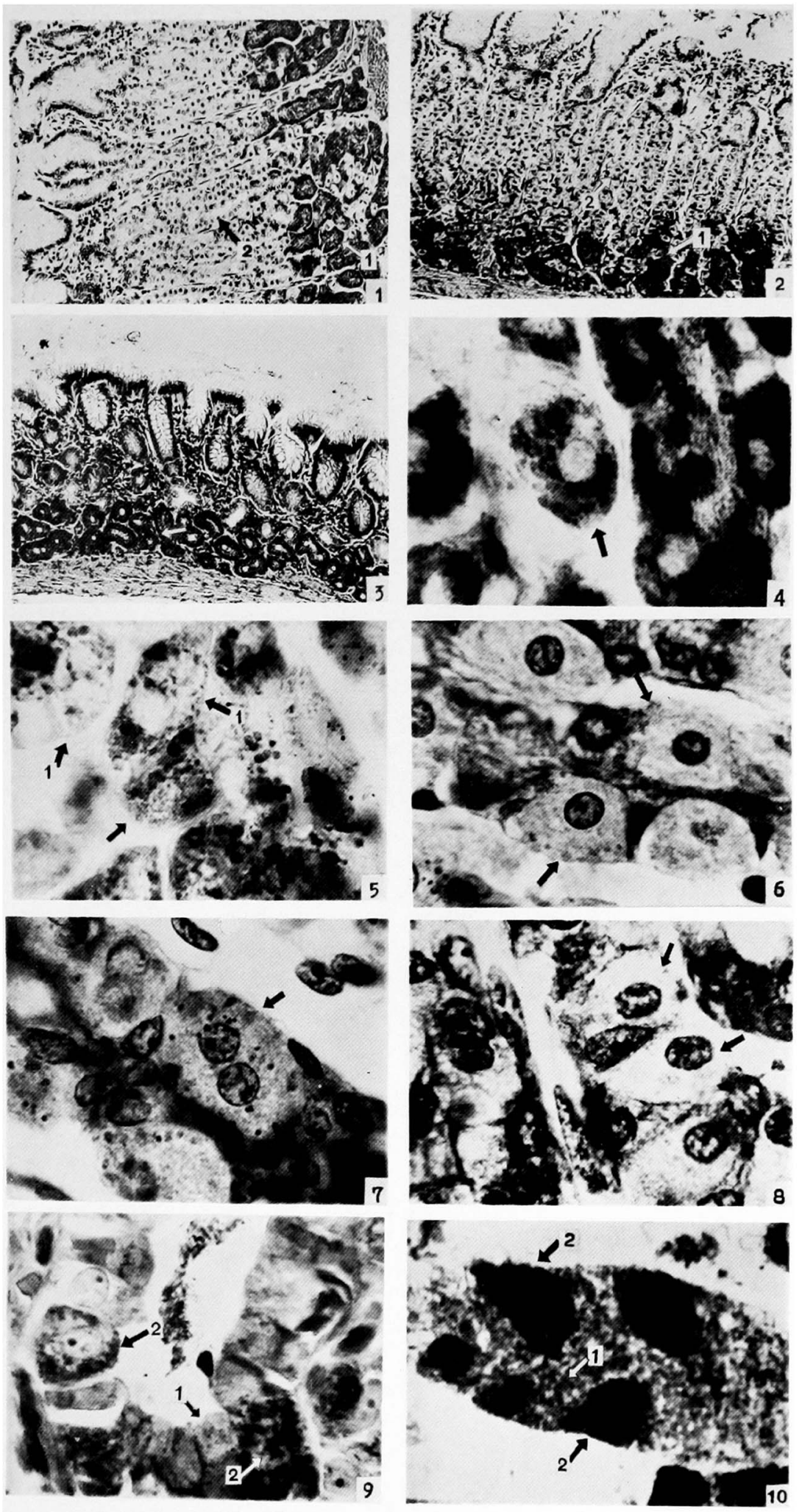


\section{Explanation of Figures}

Fig. 11. Chief cells (1), II type mucous cells (2), mucous neck cells (3) and epithel cells in the gastric pit (4). PAS reaction. $330 \times$.

Fig. 12. Chief cells $(\nearrow)$ are almost PAS negative and contain small and dark nuclei. $550 \times$.

Fig. 13. II type mucous cells $(\nearrow)$ are strongly reactive to the PAS reaction, containing large and light nuclei. 1 : Chief cells. 1000x.

Fig. 14. Metachromasia with cresyl violet is strongly seen in the chief cells (1) but the II type mucous cells (2) are slightly colored. $330 \times$.

Fig. 15. Secretory granules in the chief cells. Mitochondria are also mixed. Heide $\mathrm{n}$ h a i n's iron hematoxylin. $550 \times$.

Fig. 16. Coarse granules stained with Victoria blue in the chief cells. These granules are larger than the secretory granules. $600 x$.

Fig. 17. Metachromasia with cresyl violet is seen in the mucous neck cells $(\nearrow)$ but is more weakly colored than the chief cells. $1000 \times$.

Fig. 18. Cytoplasm of the mucous neck cells do not show such the network as those in the chief cells and the II type mucous cells. Large and light nuclei are contained. PAS reaction is weak. $1000 \times$.

Fig. 19. Basal clear cell (1) having a large nucleus and narrow and homogeneous cytoplasmic area. 2: Chief cell. Hematoxylin-eosin stain. 1000x.

Fig. 20. Argentaffine cell (1) having a large nucleus and the cytoplasm containing numerous granules. 2: Chief cell. Hematoxylin-eosin stain. 1000x. 
Plate II
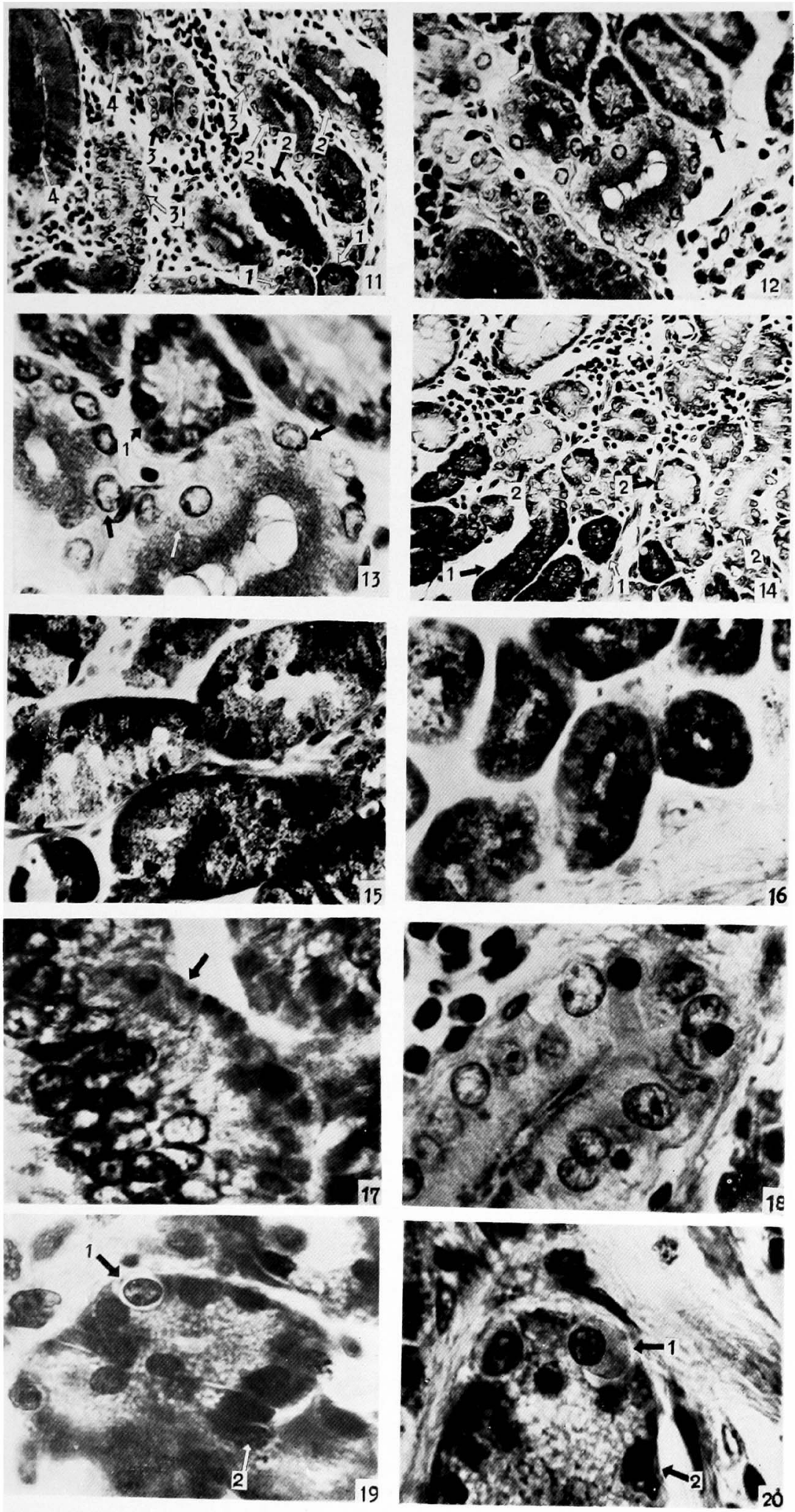

M. Imai, T. Shibata and T. Mineda 